\title{
Scientific Journal of Silesian University of Technology. Series Transport
}

Zeszyty Naukowe Politechniki Śląskiej. Seria Transport

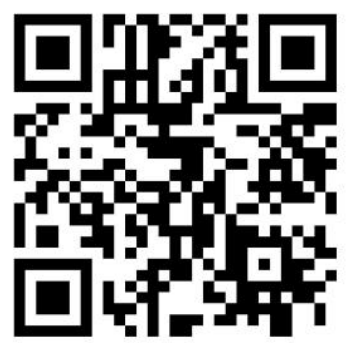

Volume 103

2019

p-ISSN: 0209-3324

e-ISSN: $2450-1549$

DOI: https://doi.org/10.20858/sjsutst.2019.103.7

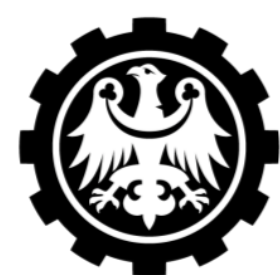

Silesian

University of Technology

Journal homepage: http://sjsutst.polsl.pl

Article citation information:

L'upták, V., Bartuška, L., Droździel, P. Assessing connection quality in passenger air transport in the context of Prague region development. Scientific Journal of Silesian University of

Technology. Series Transport. 2019, 103, 81-91. ISSN: 0209-3324.

DOI: https://doi.org/10.20858/sjsutst.2019.103.7.

\section{Vladimír LUPTÁK ${ }^{1}$, Ladislav BARTUŠKA루, Paweł DROŹDZIEL ${ }^{3}$}

\section{ASSESSING CONNECTION QUALITY IN PASSENGER AIR TRANSPORT IN THE CONTEXT OF PRAGUE REGION DEVELOPMENT}

Summary. The objective of this contribution is the application of a new methodology for assessing connectivity in passenger transport regarding selected tariff points accessibility in the context of developing the selected region. From the passenger's point of view, it is necessary to specially assess the accessibility of lines within transportation, between the selected destinations using passenger air transport. The length of the travel time, the number of necessary transfers and the number of travel opportunities affects the possibilities of transport between place A and B. The connections and lines are thus influenced by many factors. This is the basic point to consider when designing a set of evaluation criteria for assessing the connectivity and in carrying out a case study for a specific region. In this paper, Václav Havel Airport in Prague (Czech Republic) with selected air transport connections were evaluated according to the proposed methodology.

Keywords: air transport lines, passenger air transport, methodology, quality assessment in air transport

\footnotetext{
${ }^{1}$ Institute of Technology and Business in České Budějovice, Faculty of Technology, Department of Transport and Logistics, Okružní 517/10, 37001 České Budějovice, Czech Republic. Email: luptak@ mail.vstecb.cz ${ }^{2}$ Institute of Technology and Business in České Budějovice, Faculty of Technology, Department of Transport and Logistics, Okružní 517/10, 37001 České Budějovice, Czech Republic. Email: bartuska@ mail.vstecb.cz

${ }^{3}$ Lublin University of Technology,Faculty of Mechanical Engineering, Nadbystrzycka Street 36, 20-618 Lublin, Poland. Email: p.drozdziel@pollub.pl
} 


\section{INTRODUCTION}

The role of the European Union transport system is to ensure a high level of mobility, while constantly increasing its performance in terms of speed, comfort and safety. To have a consistent, integrated and efficient transport system requires creating transfer links involving all modes of transport. The accessibility of a destination and the frequency of the lines are the most important criteria in the context of passengers' interest in public transport. [1-5]

The basis of providing transport services is to offer travel opportunities by creating transport connections and links between the individual connection, that is, to assess the links and travel opportunities (connections) as such. Currently, there is no methodology for assessing travel opportunities from the transportation point of view as a whole. Within the evaluation process, the individual flights and connections at the airports are assessed, not the quality of the connection between point $\mathrm{A}$ and point $\mathrm{B}$. $[6,7]$

The case study in this paper is based on Václav Havel Airport Prague situated in the Central Bohemian Region. The specific routes (26 routes/destinations) were selected for the demonstration of the proposed assessment. Within each route, all flights operated by low-cost carriers and traditional airliners were assessed. [8,9]

Václav Havel Airport Prague is a middle-sized regional airport. In 2017, it served over 15 million passengers (expecting 17 million in 2018). In summer season 2018, 67 airlines flew to 157 destinations in Europe, Asia, Africa and North America from Prague Airport. It serves as a hub for Czech Airlines as well as a base for Travel Service including its subsidiary brand, SmartWings, and a base for low-cost carrier, Ryanair. [10-13].

\section{QUALITY OF CONNECTION}

The quality of the offered connections significantly influences the services provided in transport. The main objective of transport is to satisfy customers' requirements for quality, flexible, fast and safe transportation of passengers and goods. Quality is perceived differently from various viewpoints; transport users' and transport services providers' or organisers' and social perspective. This is due to assessing the connection quality non-systemically, regardless of the interaction of the persons transported and the transport or transportation system.

The connections offered by a transport company depends on the demand for transport from the existing customers (passengers) who for objective or subjective reasons need to move to some other place between two destinations within a transport network. [14-19]

\subsection{Methods of assessing connection in air passenger transport}

The proposed methods are based on assessing the defined criteria of the connection between the selected tariff points in passenger air transport. The base of the methods is assessing a particular connection. For this purpose, it is necessary to determine whether the connections are assessed on a working day or weekend, and prepare the evaluation specifically for the given working day, Saturday or Sunday. Subsequently, summarising indicators will be evaluated for the connection within a route as well as the entire transport network in question. [20]

To have a consistent, integrated and efficient transport system now requires creating transfer links which would include all modes of transport. The accessibility of the destination 
and frequency of the connections are the most important criteria in terms of passengers' interest in using public transport. The proposed methods for establishing the standard quality assessment metric for evaluating the connections within a network is intended to cover all possibilities of reaching any pair of tariff points within a selected transport network and by means of the selected indicators to evaluate the quality of travel opportunities provided by air carriers operating in the examined region. The evaluation will be a tool for expressing customers' satisfaction with the services offered in the region. The minimum defined connection quality standards in the region will be comprehensively evaluated using the following indicators:

- average travel speed,

- average speed until the final destination,

- average waiting time.

For a comprehensive assessment, it is necessary to analyse the quality of connections among all tariff points in the examined region. If there are $n$ tariff points in the passenger air transport network, the number of routes $(m)$ to be analysed is calculated as follows:

$$
m=n^{2}
$$

where:

$m \quad$ number of routes between the points,

$n \quad$ number of points in the selected network.

Another possibility is to choose a set of representative tariff points, which enables evaluation of quality in the entire network. [20-27]

The methods are based on assessing the defined criteria between the selected tariff points in the network. The basic principle is the evaluation of a particular connection. For this purpose, it is necessary to determine whether the assessed connection is on a working day or weekend or prepare the evaluation specifically for a selected working day, Saturday or Sunday. Subsequently, the summarising indicators will be evaluated for the connections within the routes and the entire network. [28-31]

While assessing the connectivity and quality of connection within the given route, the following factors were identified:

- Number of connections $N_{s}$ for the assessed day includes both direct flights and transfer flights. This indicates the number of alternatives divided over the time that passengers have to travel from point A to point B.

- Average waiting time $W_{i}$ refers to the amount of time spent by passengers waiting for a particular connection at the departure airport, or starting point. It is defined as half the time between the departure of two sequential connections:

$$
W_{i}=\frac{\left(t_{i+1}-t_{i}\right)}{2}[h]
$$

where:

$t_{i}$ departure time of the assessed connection from the starting point (airport).

$t_{i+1} \quad$ departure time of the connecting flight from the origin airport.

- Route length of the connection Li refers to the distance travelled in kilometres (mostly tariff) by the mode of transport used for a particular connection. This criterion is important for the calculation of the transit speed and the speed of reaching the destination.

- Type of aeroplane and carrier creating a connection. This factor expresses the quality of the connection transport service. 
- Transit time $T_{p}$. It refers to the moment of passenger's arrival to the airport 2 hours before the departure from the first tariff point and the moment of termination of the transport in the final destination.

- Number of transfers $N_{p}$ refers to the absolute number of changing the means of transport when reaching the final destination.

- Transfer waiting time $T_{w}$ is the overall time the passenger spends waiting for connections in the hubs when using a particular connection:

$$
T_{w}=\sum\left(t_{\text {i2dep }}-t_{\text {i1arr }}\right)[\mathrm{min}]
$$

where:

$t_{i 2 d e p}$ departure time of the connecting flight at the airport of the i-th transfer.

$t_{\text {ilarr }}$ time of the plane arrival to the airport of the i-th transfer.

- Reaching destination time TD refers to the time starting from the moment of passenger's arrival to the airport where they start the journey and ending with the moment of the plane's arrival at the final destination. It is calculated as a sum of the average waiting time and time of the transport:

$$
T_{D}=W_{i}+T_{P}[h]
$$

where:

$W_{i} \quad$ is average waiting time between two consecutive connections [h].

$T_{p} \quad$ is the transit time $[\mathrm{h}]$.

- Transit speed $V_{P}$ - is expressed as a quotient of the distance travelled and the time of transit:

$$
V_{p}=\frac{L_{s i}}{T_{p}}[\mathrm{~km} / \mathrm{h}]
$$

where :

$L_{s i}$ route length of the connection $[\mathrm{km}]$.

$T_{P}$ time of transit[h].

- Reaching destination speed $V_{D}$ - is expressed as a quotient of the route length of the connection and time of reaching the destination:

$$
V_{D}=\frac{L_{s i}}{T_{D}}\left[\mathrm{~km} \cdot \mathrm{h}^{-1}\right]
$$

\section{2. Assessing the connection quality in selected transport network - a case study}

The following example will illustrate the application of the proposed methodology for assessing the connection in the transport network.

\section{Step 1 - Selecting a transport network}

In terms of the proposed methodology, the case study will be applied in the air transport network for all carriers providing air transport services.

\section{Step 2 - Selecting a set of connections}

The second step includes determining a set of connections according to the methodology, which means important and frequently selected destinations from the selected tariff point.

\section{Step 3 - Selecting relevant tariff points within the transport network}

For the application of the connection quality evaluation, 26 tariff points were identified on the routes from Prague (Václav Havel Airport) to the following destinations: Madrid, Bucharest, Oslo, Stockholm, Dublin, Barcelona, Rome, Manchester, London, Copenhagen, Paris, Belgrade, Eindhoven, Amsterdam, Brussels, Milan, Istanbul, Helsinki, Hamburg, Warsaw, Zurich, Venice, Kiev, Budapest, Riga and Bratislava. 
Figure 1 shows the towns based on which the connection quality on the route from Prague (Václav Havel Airport) to the aforementioned tariff points (airports) in passenger air transport will be primarily assessed. The date selected for assessment was a working day, specifically Monday 15 November 2018.

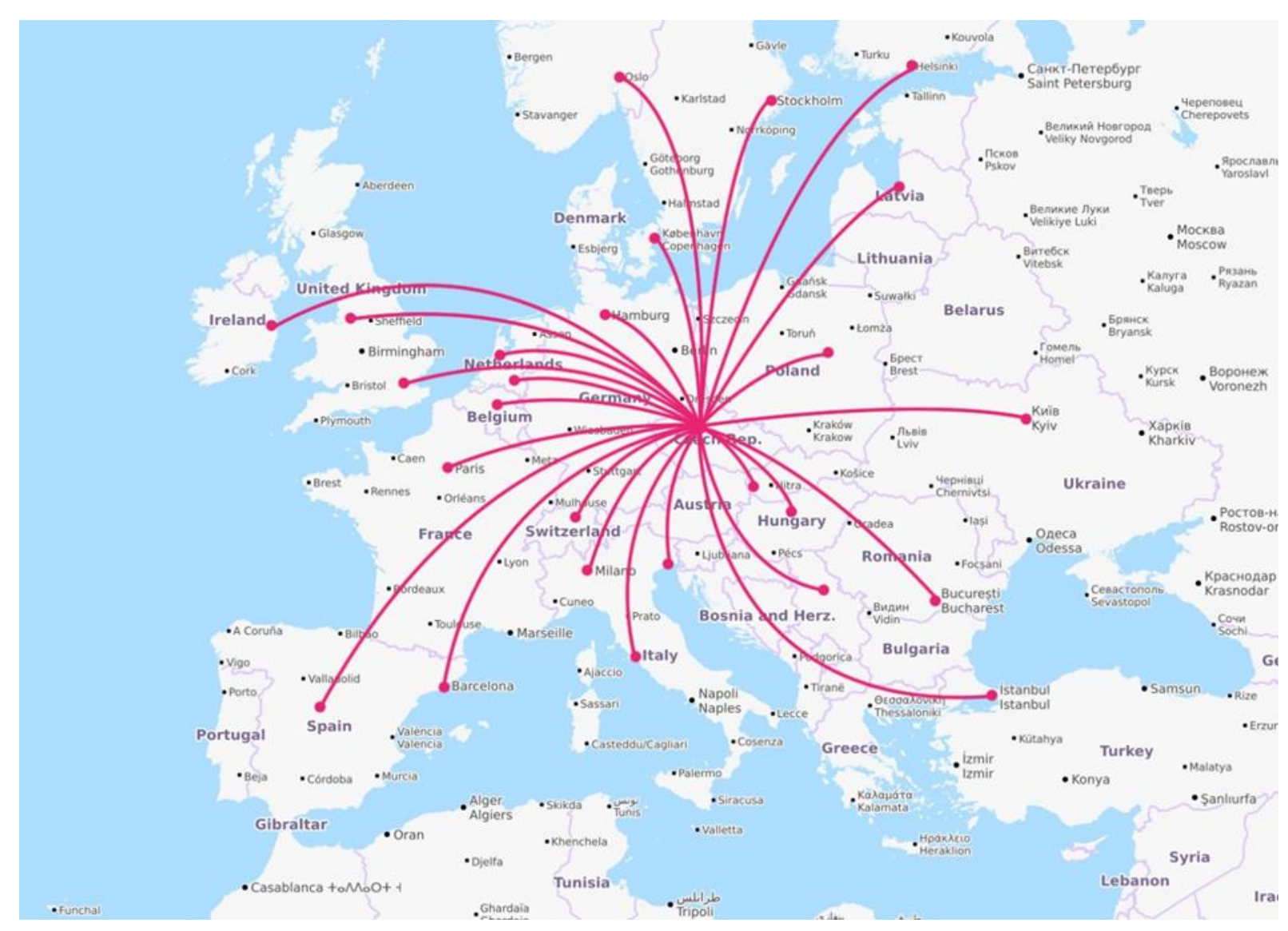

Fig. 1. Selected routes within air transport evaluated within the case study (Source: Authors)

In the context of the proposed methodology, all connections from Prague to the selected most important airports on the designated day were assessed. In this case, 26 transport routes and subsequently all connections in each route per $24 \mathrm{~h}$ were assessed comprehensively.

\section{Step 4 - Selecting a search engine for connections}

In this step, a search engine for connections needs to be chosen according to the input criteria. All connections were searched using online flight tracker (FlightMaps), an Innovata product.

\section{Step 5 - Selecting assessment indicators}

Table 1 shows a specific example, the assessment of a route between Prague and the selected destination. It is the Prague - Paris route, where 9 connections were found within 24 hours of the selected day. The highest quality connections according to the "transit time" or "flight time" criterion include the connection 9 leaving Prague at 20:35 and arriving in Paris at 22:20, travelling the distance of $853 \mathrm{~km}$ in $1.75 \mathrm{~h}$. Transfers (stop flights) were not necessary. The qualitative connection indicators are reaching destination time $\mathrm{T}_{\mathrm{d} 6}=4.50 \mathrm{~h}$, transport speed $\mathrm{V}_{\mathrm{P} 6}=487.43 \mathrm{~km} \cdot \mathrm{h}^{-1}$ and the speed of reaching the destination is $\mathrm{V}_{\mathrm{D} 6}=350.96 \mathrm{~km} \cdot \mathrm{h}^{-1}$. 
Tab. 1

Identified air transport connections in the Prague - Paris route

\begin{tabular}{|c|c|c|c|c|c|c|c|c|c|}
\hline 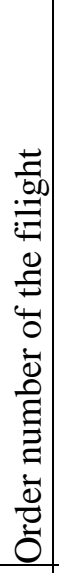 & 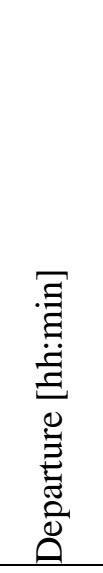 & 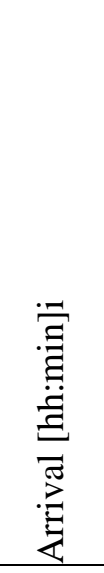 & 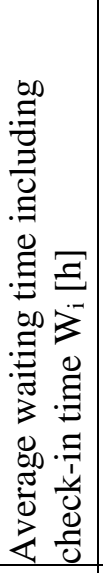 & 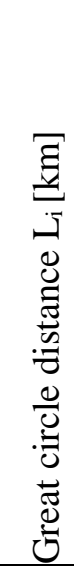 & : & 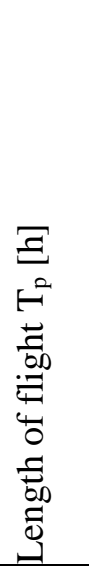 & 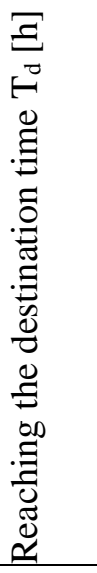 & 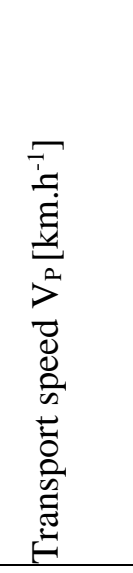 & 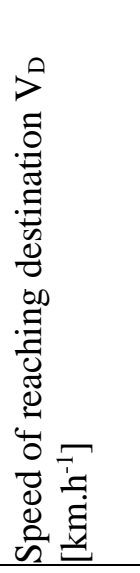 \\
\hline 1 & $7: 10$ & 9:00 & 0.00 & 853 & CSA & 1.83 & 1.83 & 465.27 & 465.27 \\
\hline 2 & $8: 35$ & 10:30 & 0.71 & 874 & Transavia & 1.92 & 2.63 & 456.00 & 332.95 \\
\hline 3 & 9:50 & $11: 40$ & 0.63 & 853 & Air France & 1.83 & 2.46 & 465.27 & 346.98 \\
\hline 4 & $12: 25$ & $14: 15$ & 1.29 & 853 & $\mathrm{CSA}$ & 1.83 & 3.13 & 465.27 & 272.96 \\
\hline 5 & $15: 25$ & $17: 10$ & 1.50 & 853 & Air France & 1.75 & 3.25 & 487.43 & 262.46 \\
\hline 6 & $17: 20$ & 19:05 & 0.96 & 853 & Vueling Air. & 1.75 & 2.71 & 487.43 & 314.95 \\
\hline 7 & $17: 35$ & 19:25 & 0.13 & 853 & $\mathrm{CSA}$ & 1.83 & 1.96 & 465.27 & 435.57 \\
\hline 8 & $20: 25$ & $22: 20$ & 1.42 & 874 & Transavia & 1.92 & 3.33 & 456.00 & 262.20 \\
\hline 9 & $20: 35$ & $22: 20$ & 0.08 & 853 & Air France & 1.75 & 1.83 & 487.43 & 465.27 \\
\hline
\end{tabular}

Step 6 - Assessment of all connections within the route

For further evaluation of the entire network, it is necessary to define the average indicators for each route. On the Prague - Paris route, the average time of reaching the destination is $ø T_{d}$ $=2.57 \mathrm{hod}$, the average transit speed $ø \mathrm{~V}_{\mathrm{P}}=487.43 \mathrm{~km} \cdot \mathrm{h}^{-1}$ and the speed of reaching the destination is $\varnothing \mathrm{V}_{\mathrm{D}}=465.27 \mathrm{~km} \cdot \mathrm{h}^{-1}$. All average indicators are listed in the following extended table.

Tab. 2

Comprehensive assessment of the Prague - Paris route

\begin{tabular}{|c|c|c|c|c|c|c|c|c|c|}
\hline 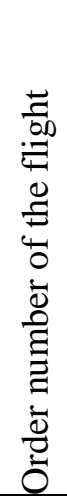 & 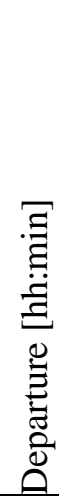 & 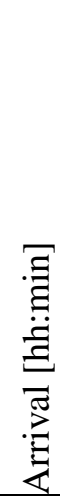 & 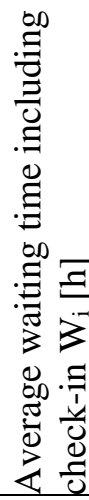 & 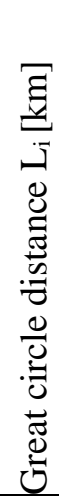 & : & 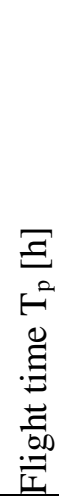 & 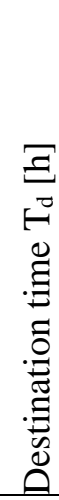 & 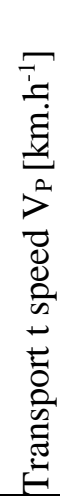 & 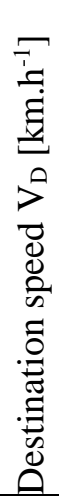 \\
\hline
\end{tabular}


Assessing connection quality in passenger air transport in the context of...

\begin{tabular}{|c|c|c|c|c|c|c|c|c|c|}
\hline 1 & $7: 10$ & 9:00 & 0.00 & 853 & CSA & 1.83 & 1.83 & 465.27 & 465.27 \\
\hline 2 & $8: 35$ & $10: 30$ & 0.71 & 874 & Transavia & 1.92 & 2.63 & 456.00 & 332.95 \\
\hline 3 & $9: 50$ & 11:40 & 0.63 & 853 & Air France & 1.83 & 2.46 & 465.27 & 346.98 \\
\hline 4 & $12: 25$ & $14: 15$ & 1.29 & 853 & $\mathrm{CSA}$ & 1.83 & 3.13 & 465.27 & 272.96 \\
\hline 5 & $15: 25$ & $17: 10$ & 1.50 & 853 & Air France & 1.75 & 3.25 & 487.43 & 262.46 \\
\hline 6 & $17: 20$ & 19:05 & 0.96 & 853 & Vueling Air. & 1.75 & 2.71 & 487.43 & 314.95 \\
\hline 7 & $17: 35$ & $19: 25$ & 0.13 & 853 & CSA & 1.83 & 1.96 & 465.27 & 435.57 \\
\hline 8 & $20: 25$ & 22:20 & 1.42 & 874 & Transavia & 1.92 & 3.33 & 456.00 & 262.20 \\
\hline 9 & $20: 35$ & $22: 20$ & 0.08 & 853 & Air France & 1.75 & 1.83 & 487.43 & 465.27 \\
\hline \multicolumn{7}{|c|}{ Average values for a route } & 2.57 & 470.6 & 350.96 \\
\hline
\end{tabular}

\section{Step 7 - The results of quality assessment on the Prague - Paris route}

In the context of the proposed methodology, all connections for each route were found in the schedule. The values of the factors were determined: the number of connections on the evaluated day, the average waiting time of the passenger $\mathrm{W}_{\mathrm{i}}$, length of the route of the connection $L_{s}$, transit time $T_{p}$, number of transfers, time of transfers $T_{w}$, time of reaching the destination $T_{D}$, speed of transit $V_{P}$ and speed of reaching the destination $V_{D}$.

Following the results, it may be concluded that the fastest reached destinations from Prague using regular passenger air transport are Madrid, Bucharest and Stockholm. This is due to the high number of travel opportunities, long distance between the destinations and connections evenly distributed within the entire day. The minimum speed of reaching the destination was in the case of Budapest, Venice and Bratislava, which resulted from "slow connections" in terms of passenger check-in before departure along with a short distance between the destinations and long waiting time due to the low number of connections.

Tab. 3

Results of connections quality assessment on the route from Prague to selected destinations

\begin{tabular}{|c|c|c|c|}
\hline 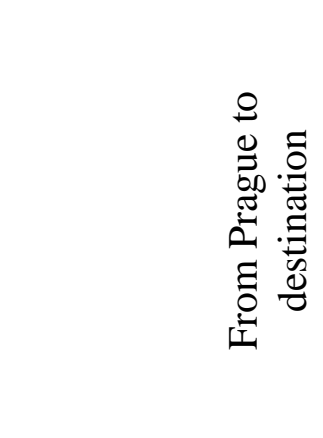 & 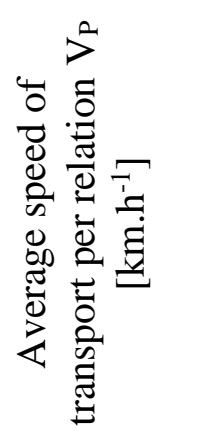 & 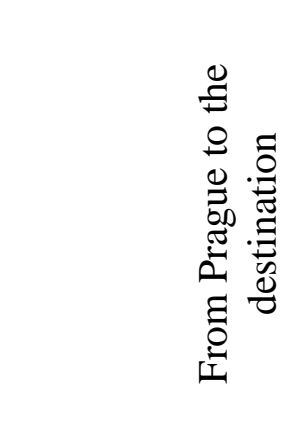 & 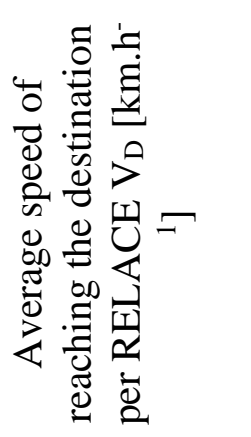 \\
\hline Madrid & 594.77 & Madrid & 512.38 \\
\hline Bucharest & 576.82 & Bucharest & 474.98 \\
\hline Oslo & 570.50 & Stockholm & 469.46 \\
\hline Stockholm & 567.00 & Dublin & 444.29 \\
\hline Dublin & 564.20 & Oslo & 434.34 \\
\hline Barcelona & 562.76 & Rome & 434.01 \\
\hline Rome & 537.59 & Eindhoven & 419.19 \\
\hline Manchester & 517.60 & London & 412.68 \\
\hline
\end{tabular}




\begin{tabular}{|l|r|l|r|}
\hline London & 500.48 & Barcelona & 398.21 \\
\hline Copenhagen & 475.04 & Hamburg & 392.80 \\
\hline Paris & $\mathbf{4 7 0 . 6 0}$ & Manchester & 378.76 \\
\hline Belgrade & 456.68 & Belgrade & 378.54 \\
\hline Eindhoven & 453.18 & Paris & $\mathbf{3 5 0 . 9 6}$ \\
\hline Amsterdam & 449.56 & Helsinki & 347.30 \\
\hline Brussels & 448.67 & Istanbul & 333.78 \\
\hline Milan & 439.78 & Amsterdam & 318.11 \\
\hline Istanbul & 426.07 & Brussels & 317.54 \\
\hline Helsinki & 420.76 & Copenhagen & 275.57 \\
\hline Hamburg & 406.83 & Warsaw & 256.93 \\
\hline Warsaw & 374.47 & Milan & 241.97 \\
\hline Zurich & 372.71 & Kiev & 238.91 \\
\hline Venice & 358.43 & Zurich & 231.18 \\
\hline Kiev & 356.78 & Riga & 219.44 \\
\hline Budapest & 349.54 & Budapest & 211.15 \\
\hline Riga & 322.05 & Venice & 210.28 \\
\hline Bratislava & 304.00 & Bratislava & 174.38 \\
\hline Average value per route & 456.80 & Average value per route & 341.43 \\
\hline
\end{tabular}

\section{CONCLUSION}

The applied methodology covers the possibilities of reaching the selected pair of tariff points in regular passenger air transport. The methodology provides not only evaluation of the connectivity within the selected route, but also an objective assessment of the accessibility between two selected tariff points on the basis of qualitative indicators, such as the average transport speed and the average speed of reaching the destination. It assesses comprehensively, the quality of provided travel opportunities in passenger air transport in the selected area, considering the context of the development of the Prague region and the Czech Republic using selected indicators.

The methodology summarises the findings from the passenger transport theory and assists in assessing the quality of available passenger air transport services across Europe.

\section{Acknowledgement}

This contribution was created within the solution of the Czech research project LTC17040 named "Regionální letiště v České a Slovenské republice a vliv jejich provozu na ekonomický rozvoj regionu" of the INTER-EXCELLENCE program, an INTER-COST subprogram. 


\section{References}

1. Drdla Pavel. 2014. Osobní doprava regionálního a nadregionálního významu. [In Slovak: Passenger transport of regional and supra-regional importance]. Pardubice. University of Pardubice. ISBN 978-80-7395-787-2.

2. Halás Martin, Jozef Gašparík, Jaromír Široký, Lumír Pečený. 2014. „Methodology for assesing the quality of the connection on network". Communications - Scientific Journal of Zilina University 16(2). ISSN 1335-4205.

3. Dlugos Matus, Lumir Peceny, Pavol Mesko, Peter Sulko. 2017. "The impact of delays of freight trains in JIT System on example one track line". In "LOGI 2018" Conference. MATEC Web of Conferences 134. DOI: 10.1051/matecconf/201713400011.

4. Poliak Milos, Adela Paliakova, Michaela Mrinkova, Marek Jaśkiewicz, Rafał Jurecki. 2017. “The competitiveness of public”. Journal of Competitiveness 9(3): 81-97. WOS: 000415332500007.

5. Vlatka Stupalo, Alen Jugovic, Ante Mrvica. 2016. "Quantitative analysis of maritime passenger transport in Europe". Nase More 63(4): 256-262.

6. Sipus Denis, Borna Abramovic. 2017. "The possibility of using public transport in rural area”. Procedia Engineering 192: 788-793. DOI: 10.1016/j.proeng.2017.06.136.

7. Jaskiewicz Marek, Grzegorz Koralewski, Jerzy Stoklosa. 2018. “Adaptation of city buses to the needs of airport terminal passenger transport". In Conference 11th International Scientific and Technical Conference on Automotive Safety. WOS: 000435296000002.

8. Buldeo Rai Heleen, Sara Verlinde, Jan Merckx, Cathy Macharis. 2017. "Crowd logistics: an opportunity for more sustainable urban freight transport?". European Transport Research Review 9(3). DOI: 10.1007/s12544-017-0256-6.

9. Ittmann Hans W. 2017. "Private-public partnerships: A mechanism for freight transport infrastructure delivery?". Journal of Transport and Supply Chain Management 11(a262). DOI: https://doi.org/10.4102/jtscm.v11i0.262.

10. Cerna Lenka, Vladislav Zitricky, Jan Ponicky. 2016. "Income and price elasticity of demand for transport services in rail passenger transport in the Slovak republic". In 34th international conference - Mathematical methods in economics: 126-131. Liberec, Czech Republic, September 2016.

11. Chen Zhenhua, Kingsley E. Haynes. 2017. "Impact of high-speed rail on regional economic disparity in China". Journal of Transport Geography 65: 80-91. DOI: 10.1016/j.jtrangeo.2017.08.003.

12. Vojtek Martin, Martin Kendra, Vladislav Zitrický, Jozef Daniš. 2017. "Principles of logistics applied to railway passenger transport”. In „LOGI 2018” Conference. MATEC Web of Conferences 134. DOI: 10.1051/matecconf/201713400061.

13. Havenga Jan H. 2018. "Logistics and the future: The rise of macrologistics". Journal of Transport and Supply Chain Management |12(a336). DOI: https://doi.org/10.4102/jtscm.v12i0.336.

14. Hrabáček Jan. 2010. „Periodická doprava na dopravních sítích a její optimalizace”. [In Czech: "Periodic traffic at transport network and its oprimation"]. PhD thesis. Pardubice: Univerzity of Pardubice, Jan Perner Transport Faculty, Czech Republic.

15. Rybicka Iwona, Jacek Caban, Ján Vrábel, Branislav Šarkan, Ondrej Stopka, Wojciech Misztal. 2018. „Analysis of the safety systems damage on the example of a suburban transport enterprise". In XI International Science Technical Conference Automotive Safety. ISBN 978-1-5386-4578-9. 
16. Stopková Mária, Ondrej Stopka, Martina Hlatká. 2018. „Material deliveries rationalization by utilizing the specific designed methodology". In 22st International Scientific Conference Transport Means 2018. Kaunas, Lithuania: Kaunas University of Technology. ISSN 1822-296X.

17. Kalra Geet, Varun Chotia Amit Goel. 2016. "Investigating the relationship between transport infrastructure and economic growth: the case of India". Indian Journal of Economics and Development 12(2): 315-320. DOI: 10.5958/23220430.2016.00141.4.

18. Milan Dedík. 2016. „Quality assessment of connection in passenger rail transport from a network perspective". Diploma thesis, Zilina: University of Zilina, Slovak Republic.

19. Skrucany Tomas, Martin Kendra, Milan Skorupa, Juraj Grencik, Tomasz Figlus. 2017. "Comparison of chosen environmental aspects in individual transport and road railway passenger transport". Transcom: 806-811. DOI: 10.1016/j.proeng.2017.06.139.

20. Isikli Erkan, Nezir Aydin, Erkan Celik, Alev Taskin Gumus. 2017. "Identifying key factors of rail transit service quality: an empirical analysis for Istanbul". Journal of Public Transportation 20(1): 63-90. ISSN 1077-291X.

21. Kostolná Mária, Vladimír Konečný. 2014. "Quality standardization of transport services in public passenger transport". Logi - Scientific Journal on Transport and Logistics 5(2): 5-10. ISSN 1804-3216.

22. The European Parliament and the Council of the European Union. "The Regulation (EC) No 1371/2007 of the European Parliament and of the Council of 23 October 2007 on rail passengers' rights and obligations". Official Journal of the European Union, 2007.

23. Kendra Martin, Jarosla Masek, Jan Ponicky, Tomas Skrucany. 2016. "Proposal of methodology for calculating the quantity of validation machines in railway transport". Transportation Research Proceedia 14: 977-1986. DOI: 10.1016/j.trpro.2016.05.165.

24. Gasparik Jozef, Vladislav Zitricky. 2010. "A new approach to estimating the occupation time of the railway infrastructure". Transport 25 (4): 387-393. DOI: 10.3846/transport.2010.48.

25. Camaj Juraj, Jaroslav Masek, Martin Kendra. 2016. "Model of the location the marshalling yards in slovak conditions". In 20th International Scientific Conference on Transport Means 2016: 140-144. Kaunas University of Technology. October 2016, Juodkrante, Lithuania. ISSN: 1822-296X.

26. Jacyna-Gołda Ilona, Mariusz Wasiak, Mariusz Izdebski, Konrad Lewczuk, Roland Jachimowski, Dariusz Pyza. 2016. „The evaluation of the efficiency of supply chain configuration". Proceedings of the 20th International Scientific Conference Transport Means 2016. Transport Means - Proceedings of the International Conference: 953-957.

27. Rocco Giordano. 2018. "A renewed economic policy of transports". European Transport/Trasporti Europei 70(1). ISSN 1825-3997.

28. Kampf Rudolf, Silvia Lorincová, Miloš Hitka, Ondrej Stopka. 2017. „Generational differences in the perception of corporate culture in european transport enterprises". Sustainability 9(9): 1-14. ISSN 2071-1050.

29. Gołda Pawel, Mariusz Zieja. 2015. „Risk analysis in air transport”. Transport Means 2015. Transport Means - Proceedings of the International Conference: 620-623.

30. Gunarathna Prageeth, Hassan, Rayya. 2016. "Sustainability assessment tool for road transport asset management practice". Road \& Transport Research: A Journal of Australian and New Zealand Research and Practice 25(4): 15-26. 
31. Kowalski M. 2014. "An analysis of failure symptoms of the airscrew drive in the PZL130-TCI Orlik Aircraft”. Journal Of Vibration Engineering \& Technologies 2(4): 315326.

Received 13.01.2019; accepted in revised form 02.05.2019

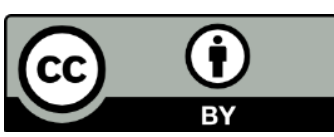

Scientific Journal of Silesian University of Technology. Series Transport is licensed under a Creative Commons Attribution 4.0 International License 